\title{
「家族」とその生活
}

\section{Family Studies Focused on the Local Community Life}

\section{玉 水 俊 哲}

筆者は，家族とその生活を考える場合，集団的生活体または集合的な生活家庭としてと らえることが必要だと考えてきた。

これは, 筆者が調査・研究の最初に取りかかった対象が,「エネルギー革命」の名の下に 進められていた石炭産業の合理化であり, なかでも, 大手石炭産業として注目されたのが, 三井・三池炭鉱の合理化であった。総評傘下の炭労は，他炭坑労組や多くの労組，または 大牟田を中心とした地域組織からの支援を受けて，石炭産業合理化反対闘争を組織してい た. まさに，戦後労働争議の中でも総資本対総労働の様相をむつものであった.

そのことと同時に，子どもの「しつけ・子育てと子どもの性格形成」に関心をむってい た筆者は，家族の形態と子どもの性格形成の関係について手近の幼稚園を対象にして調查 を行っていた，その中で，家族の形態の相違よりも家族の生活が行われる「地域社会」の 方が变数としては優位であることに気がついた.

そこで, 異なった地域の子どもの生活と性格形成の調査を行うことが必要だと考え, 産 炭地域と地方都市 (北九州市) を対象とする調查を試みた.

実際には, 対象地域として炭坑町（福岡県鞍手郡小竹町・旧古河産業小竹炭坑の炭住街） と北九州の中心都市としての小倉を選び，両地域の幼児教育機関，幼稚園・保育所の子ど あの性格形成の相違を調査することにした。 そこでも確認されたのが, 生活地域一家族形態 一しつけ・育児様態の図式であった。これらの経験から導き出されたのが, 以下に述べる論 理構造である.

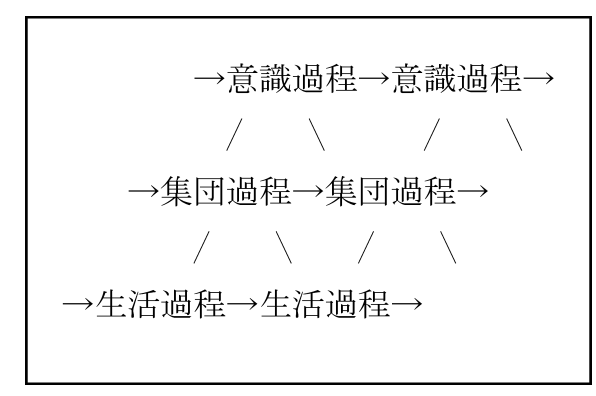

図 1

Toshiaki Tamamizu 


\section{JADANESEJOURNALOFFAVIIVSOGLLOGV}

武谷三男氏の「現象論的段階・実体論的段階・本質論的段階」という三段階論や西山卯 三氏の住居論または生活空間論などの検討を踏まえて，家族と生活の問題を考えた.

上図は，筆者が家族を考える場合の基本的な論理構造である。『家族社会学研究』(1:16) を参照いただきたい。

上図を前提として，現代家族の一般的意味においても，また象徵的意味においても，「労 働者家族」がその中心的な位置を占めると考えられるが，その労働者家族の生活が行われ る時間的・空間的範囲として，“労働生活・家庭生活・地域生活”というそれぞれの生活空 間を視野に入れておく必要があると考える.

また，生活過程-集団過程一意識過程それぞれの分析と解析が必要であり，諸過程の相互 関連の詳細な解析もまた必要である.

さらに，図 1 の諸過程と労働空間・家庭生活空間・地域生活空間の相互に絡み合う生活 の実態の土台または背景として，それぞれの国または地域の経済的・政治的発展過程との 関連性を跡づけておく必要があると考える。

勿論，上述に示した研究枠組みは，必要ではあるけれどあ，大枠過ぎるし，それぞれの 諸過程についての詳細な説明およびそれぞれの諸過程の実証的な調査と実証が必要である ことは論をまたないのは，言うまでもない，なによりも，複雑で多様な「意識過程」の分 析と解析は重要であろう。抏そらはフロイトの人格形成理論とその手法があつ意味は大 きいと思う。

しかし, 従来から行われてきている詳細で緻密な調査や研究のもつ重要性とその積み上 げによる諸理論的な枠組みが現実的な意味合いにおいて，「家族とその生活」について何を 明らかにし，明らかにしてこなかったか，厳密な検証がなされなければならないこともま た事実である。

「家族問題研究学会」や「日本家族社会学会」また関連諸学会などで，それぞれ努力がな

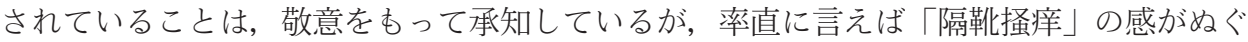
えないのはなぜであろうか。これは，筆者の勝手な思い込みだけではないように思うのだ が. 